\title{
Salt-stimulation of caesium accumulation in the euryhaline green microalga Chlorella salina: potential relevance to the development of a biological Cs-removal process
}

\author{
Simon V. Avery, $\dagger$ Geoffrey A. Codd and Geoffrey M. GadD* \\ Department of Biological Sciences, University of Dundee, Dundee DDI 4HN, UK \\ (Received 7 December 1992; revised 17 March 1993; accepted 26 April 1993)
}

\begin{abstract}
Accumulation of $\mathrm{Cs}^{+}$by Chlorella salina was 28 -fold greater in cells incubated in the presence than in the absence of $0.5 \mathrm{M}-\mathrm{NaCl}$. An approximate $70 \%$ removal of external $\mathrm{Cs}^{+}$resulted after $15 \mathrm{~h}$ incubation of cells with $50 \mu \mathrm{M}-$ $\mathrm{CsCl}$ and $0.5 \mathrm{M}-\mathrm{NaCl}$. $\mathrm{LiCl}$ also had a stimulatory effect on $\mathrm{Cs}^{+}$uptake, although mannitol did not. $\mathrm{Cs}^{+}$influx increased with increasing external $\mathrm{NaCl}$ concentration and was maximal between $25-500 \mathrm{~mm}-\mathrm{NaCl}$ at approximately $4 \mathrm{nmol} \mathrm{Cs}{ }^{+} \mathrm{h}^{-1}\left(1^{6} \text { cells }\right)^{-1}$. Little effect on $\mathrm{Cs}^{+}$uptake resulted from the presence of $\mathrm{Mg}^{2+}$ or $\mathrm{Ca}^{2+}$ or from varying the external $\mathrm{pH}$, and $\mathrm{Cs}^{+}$was relatively non-toxic towards $C$. salina. At increasing cell densities (from $4 \times 10^{5}$ to $1 \times 10^{7}$ cells ml ${ }^{-1}$ ), decreasing amounts of $\mathrm{Cs}^{+}$were accumulated per cell although the rate of $\mathrm{Cs}^{+}$ removal from the external medium was still greatest at the higher cell densities examined. Freely suspended $C$. salina and cell-loaded alginate microbeads accumulated similar levels of $\mathrm{Cs}^{+}$, however, $46 \%$ of total $\mathrm{Cs}^{+}$uptake was attributable to the calcium-alginate matrix in the latter case. When $\mathrm{Cs}^{+}$-loaded cells were subjected to hypoosmotic shock, loss of cellular $\mathrm{Cs}^{+}$occurred allowing easy $\mathrm{Cs}^{+}$recovery. This loss exceeded $90 \%$ of cellular $\mathrm{Cs}^{+}$ when cells were washed with solutions containing $\leqslant 50 \mathrm{mM}-\mathrm{NaCl}$ between consecutive $\mathrm{Cs}^{+}$uptake periods; these cells subsequently lost their ability to accumulate large amounts of $\mathrm{Cs}^{+}$. Maximal $\mathrm{Cs}^{+}$uptake (approximately $85.1 \%$ removal after three $15 \mathrm{~h}$ incubations) occurred when cells were washed with a solution containing $500 \mathrm{~mm}$ $\mathrm{NaCl}$ and $200 \mathrm{mM}-\mathrm{KCl}$ between incubations. The relevance of these results to the possible use of $C$. salina in a saltdependent biological Cs-removal process is discussed.
\end{abstract}

\section{Introduction}

The contamination of aquatic ecosystems by ${ }^{137} \mathrm{Cs}$, that may result from the discharge of radioactive waste effluents from nuclear reactors and nuclear fuel reprocessing plants, is of environmental concern due to the long half-life of ${ }^{137} \mathrm{Cs}(\sim 30$ years) and the toxic effects that may result from its accumulation into food chains (Avery et al., 1992a). As a consequence, the removal of ${ }^{137} \mathrm{Cs}$ from waste effluents, to acceptable residual levels prior to discharge, is essential. One alternative to the use of chemical methods for the removal of other metals from solution, that has received attention in recent years, is biosorption (Gadd, 1992). Many biosorption studies have utilized denatured biomass to eliminate the toxic

\footnotetext{
*Author for correspondence. Tel. (0382) 23181 ext. 4266; fax (0382) 22318.

$\dagger$ Present address: School of Pure and Applied Biology, University of Wales College of Cardiff, PO Box 915, Cardiff CF1 3TL, UK.
}

effects of certain metals or to increase the biosorptive capacity of the biomass (Gadd, 1990; Avery \& Tobin, 1992). However, microbial $\mathrm{Cs}^{+}$accumulation is metabolism-dependent and is mediated by cellular $\mathrm{K}^{+}$ transport systems in most cases (Avery et al., 1992a). Because of the low bioconcentration factors that are generally observed for $\mathrm{Cs}^{+}$(Plato \& Denovan, 1974; Avery et al., 1991), an efficient microbial Cs-removal process requires an effective means of stimulating active $\mathrm{Cs}^{+}\left(\mathrm{K}^{+}\right)$influx.

Among the mechanisms employed by many halotolerant micro-organisms to adapt to increases in external salinity is increased $\mathrm{K}^{+}$accumulation (Gilmour, 1990). In Escherichia coli, several different $\mathrm{K}^{+}$transport systems occur (Walderhaug et al., 1987) although those under osmotic control are distinct from the system that mediates $\mathrm{Cs}^{+}$uptake (Macaskie, 1991). However, Pick et al. (1986) detected a single $\mathrm{K}^{+}$system in the halotolerant microalga Dunaliella salina, and recent work has demonstrated that a single mechanism also mediates $\mathrm{Cs}^{+}$uptake in Chlorella salina (Avery et al., 1993). It is likely 
therefore that any factor that influences $\mathrm{K}^{+}$uptake in these organisms will also affect $\mathrm{Cs}^{+}$uptake.

The purpose of this study was to assess the potential of C. salina for $\mathrm{Cs}^{+}$removal and recovery in the presence of varying external $\mathrm{NaCl}$ concentrations.

\section{Methods}

Organism and culture conditions. Axenic cultures of Chlorella salina Kufferath CCAP $211 / 25$ were grown at $22^{\circ} \mathrm{C}$ in $100 \mathrm{ml} \mathrm{MN}$ medium of composition $\left(\mathrm{mg} \mathrm{l}^{-1}\right.$ ): $\mathrm{MgSO}_{4} \cdot 7 \mathrm{H}_{2} \mathrm{O}, 37.5 ; \mathrm{CaCl}_{2} .2 \mathrm{H}_{2} \mathrm{O}, 18 \cdot 0$; $\mathrm{NaNO}_{3}, 750 \cdot 0 ; \mathrm{K}_{2} \mathrm{HPO}_{4}, 20 \cdot 0$; citric acid, 3-0; $\mathrm{FeSO}_{4} \cdot 7 \mathrm{H}_{2} \mathrm{O}, 3 \cdot 0$; EDTA (disodium salt), $0.5 ; \mathrm{Na}_{2} \mathrm{CO}_{3}, 20.0 ; \mathrm{H}_{3} \mathrm{BO}_{3}, 2.68 ; \mathrm{MnCl}_{2} .4 \mathrm{H}_{2} \mathrm{O}$, $1.81 ; \mathrm{ZnSO}_{4} .7 \mathrm{H}_{2} \mathrm{O}, 0.222 ; \mathrm{Na}_{2} \mathrm{MoO}_{4} \cdot 2 \mathrm{H}_{2} \mathrm{O}, 0.39 ; \mathrm{CuSO}_{4} .5 \mathrm{H}_{2} \mathrm{O}$, $0-079 ; \mathrm{Co}\left(\mathrm{NO}_{3}\right)_{2} .6 \mathrm{H}_{2} \mathrm{O}, 0.049$; in $75 \%\left(\mathrm{v} / \mathrm{v}_{\mathrm{aq}}\right.$ distilled water $)$ filtered seawater (obtained from East Rock, St Andrews, Scotland, UK; filtered using Whatman no. 1 filter papers). Cultures were incubated in $250 \mathrm{ml}$ Erlenmeyer flasks with rotary aeration at $150 \mathrm{cycles} \mathrm{min}^{-1}$ and a photon fluence irradiance incident on the surface of the flasks of $120 \mu \mathrm{mol} \mathrm{m}^{-2} \mathrm{~s}^{-1}$, provided by white fluorescent light tubes. To examine the effect of $\mathrm{CsCl}$ on growth, cells from the late exponential growth phase were inoculated to an initial density of approximately $2 \times 10^{5}$ cells ml ${ }^{-1}\left(\mathrm{OD}_{680} \sim 0.1\right)$, in $100 \mathrm{ml} \mathrm{MN}$ medium containing the desired amount of $\mathrm{CsCl}$, and were incubated as above. Cell numbers were determined after appropriate dilution with distilled water, using a modified Fuchs-Rosenthal haemocytometer.

Short term $\mathrm{Cs}^{+}$uptake experiments. Cells from the late exponential growth phase were collected by centrifugation $(1200 \mathrm{~g}, 10 \mathrm{~min})$, washed thoroughly with 10 mM-TAPS buffer containing $0.5 \mathrm{M}-\mathrm{NaCl}$ (unless otherwise specified), adjusted to $\mathrm{pH} 8.0$ using $1 \mathrm{M}-\mathrm{NaOH}$ (unless otherwise specified), and suspended to a density of approximately $10^{6}$ cells ml ${ }^{-1}$ in $20 \mathrm{ml}$ of the same buffer. The suspension was then equilibrated for $1 \mathrm{~h}$ at $22^{\circ} \mathrm{C}$ and a photon fluence irradiance of $120 \mu \mathrm{mol} \mathrm{m} \mathrm{m}^{-2} \mathrm{~s}^{-1} . \mathrm{Cs}^{+}$uptake was initiated by the addition of $\mathrm{CsCl}$ to the required concentration, with ${ }^{137} \mathrm{Cs}$ (Amersham), added as a tracer to a final activity of $0.93-7.40 \mathrm{kBq} \mathrm{m}^{-1}$. Where required, either $\mathrm{NaCl}$, $\mathrm{MgCl}_{2} .6 \mathrm{H}_{2} \mathrm{O}, \mathrm{CaCl}_{2} .6 \mathrm{H}_{2} \mathrm{O}$ or mannitol, at the desired concentration, was added to the cell suspension with the $\mathrm{CsCl}$ and ${ }^{137} \mathrm{Cs}$. At intervals, $200 \mu \mathrm{l} \mathrm{samples}$ were removed and harvested by centrifugation $(8000 \mathrm{~g}$, $30 \mathrm{~s})$ through a layer comprising $40 \%$ (v/v) Dow-Corning 550 silicone oil and $60 \%(\mathrm{v} / \mathrm{v})$ bis-3,3,5-trimethylhexylphthalate (Fluka) in $500 \mu \mathrm{l}$ Beckman PRO22 plastic tubes, using an Eppendorf 5412 microcentrifuge. The bottom of each tube was cut off and placed in $5 \mathrm{ml}$ Ecoscint A scintillation fluid (National Diagnostics) for $24 \mathrm{~h}$ before measuring radioactivity using a Packard Minaxi tri-carb 4000 scintillation counter. To determine radioactivity in the external medium, $200 \mu \mathrm{l}$ samples of supernatant were taken following centrifugation of cells $(1200 \mathrm{~g}, 10 \mathrm{~min})$ and analysed as described above. To assess the effect of $\mathrm{pH}$ on $\mathrm{Cs}^{+}$accumulation, cells were treated as above but washed and finally suspended in the following buffers (all $10 \mathrm{~mm}$ ) with $0.5 \mathrm{M}-\mathrm{NaCl}$, at the specified $\mathrm{pH}$ values: HEPES, pH 7; TAPS, $\mathrm{pH} 8$ and 9; CHES, $\mathrm{pH}$ 10. The final $\mathrm{pH}$ was again adjusted using $1 \mathrm{M}-\mathrm{NaOH}$. All glassware was washed with $1 \mathrm{M}-\mathrm{HCl}$ and rinsed thoroughly with distilled deionized water prior to use.

Production of alginate microbeads and preparation for $\mathrm{Cs}^{+}$uptake experiments. A microbead maker (obtained from Dr Gudmund SkjakBraek, Institute of Biotechnology, University of Trondheim, Norway) was used to produce alginate beads of approximate diameter $0.5 \mathrm{~mm}$. This technique relies on a high air flow, running down the outside of a needle containing alginate gel to prematurely dislodge gel droplets that form at the end of the needle. Gravity alone was sufficient to draw the gel through the needle, allowing a rate of bead formation exceeding
$240 \mathrm{~min}^{-1}$. Bead size was varied by adjusting the rate of air flow. A cell suspension of $C$. salina, of the appropriate cell density, was prepared as described above in $10 \mathrm{mM}$-TAPS buffer $+0.5 \mathrm{M}-\mathrm{NaCl}, \mathrm{pH} 8$, and mixed with an equal volume $(25 \mathrm{ml})$ of $2 \%(\mathrm{w} / \mathrm{v})$ sterile sodium alginate. For unloaded beads, sodium alginate was mixed with sterile buffer. The appropriate mixture was placed in the sterilized bead-maker chamber and the top was sealed. An air flow of approximately $30 \mathrm{ml} \mathrm{min}^{-1}$ was applied to the top of the bead maker to produce microbeads of diameter $0.5 \mathrm{~mm}$. As beads were formed they were dropped into a sterile solution of $0 \cdot 2 \mathrm{M}-\mathrm{CaCl}_{2}$, at $4{ }^{\circ} \mathrm{C}$, and allowed to harden for $1 \mathrm{~h}$. The beads were then washed thoroughly in $\mathrm{MN}$ medium to remove excess $\mathrm{Ca}^{2+}$, transferred to $250 \mathrm{ml}$ Erlenmeyer flasks containing $100 \mathrm{ml}$ $\mathrm{MN}$ medium and incubated for $24 \mathrm{~h}$ in the light with shaking, as described above for culture conditions. For $\mathrm{Cs}^{+}$uptake experiments, $10 \mathrm{ml}$ of bead suspension was placed in a $10 \mathrm{ml}$ measuring cylinder and, following settling of beads, the supernatant was removed by Pasteur pipette to allow addition of a further volume of bead suspension. This process was repeated until $7.5 \mathrm{ml}$ packed beads were obtained. These were removed, washed and resuspended in $20 \mathrm{ml} 10 \mathrm{~mm}$-TAPS buffer $+0.5 \mathrm{M}-\mathrm{NaCl}, \mathrm{pH} 8$, in $100 \mathrm{ml}$ conical flasks and incubated under a photon fluence irradiance of $120 \mu \mathrm{mol} \mathrm{m}^{-2} \mathrm{~s}^{-1} . \mathrm{Cs}^{+}$accumulation was initiated by the addition of $\mathrm{CsCl}$, labelled with ${ }^{137} \mathrm{Cs}$ (final activity $\sim 4.6 \mathrm{kBq} \mathrm{ml}^{-1}$ ), to a final concentration of $50 \mu \mathrm{M}$. At intervals beads were separated from the suspending medium as described above for free cells. Samples $(100 \mu \mathrm{l})$ of the resultant supernatant were added to $5 \mathrm{ml}$ scintillation fluid and analysed for radioactivity as described above.

\section{Results}

Effect of $\mathrm{NaCl}$ on $\mathrm{Cs}^{+}$accumulation by C. salina

Accumulation of $\mathrm{Cs}^{+}$after $2 \mathrm{~h}$ incubation in the presence of $0.5 \mathrm{M}-\mathrm{NaCl}$ was approximately 28 -fold higher than for cells incubated in the absence of $\mathrm{NaCl}$ (Table 1). $\mathrm{LiCl}$ had one-half of the stimulatory effect of $\mathrm{NaCl}$ on $\mathrm{Cs}^{+}$ accumulation. Mannitol, at 0.05 or $1.0 \mathrm{M}$, did not markedly stimulate $\mathrm{Cs}^{+}$accumulation (Table 1). The initial rate of active $\mathrm{Cs}^{+}$uptake $(20-120 \mathrm{~min}$, after cellwall binding) by C. salina was determined over a range of $\mathrm{NaCl}$ concentrations in the presence of $50 \mu \mathrm{M}-\mathrm{CsCl}$ (Fig. 1). $\mathrm{Cs}^{+}$influx was lowest at $50 \mu \mathrm{M}-\mathrm{NaCl}$ [approximately

\section{Table 1. Effect of $\mathrm{NaCl}, \mathrm{LiCl}$ and mannitol on $\mathrm{Cs}^{+}$ accumulation by $C$. salina}

Cells were harvested after $2 \mathrm{~h}$ incubation in $10 \mathrm{~mm}$-TAPS buffer, adjusted to $\mathrm{pH} 8$ using tetramethylammonium hydroxide, with $1 \mathrm{mM}-\mathrm{CsCl}$ and the specified addition. Mean values from three replicate determinations are shown $\pm \mathrm{sE}$.

\begin{tabular}{ccc}
\hline \hline $\begin{array}{c}\text { Addition } \\
\text { to external } \\
\text { medium }\end{array}$ & $\begin{array}{c}\text { Concn } \\
(\mathrm{M})\end{array}$ & $\begin{array}{c}\text { Intracellular } \\
\mathrm{Cs}^{+} \\
{\left[\mathrm{nmol}^{6}\right.} \\
\left.\left(10^{6} \text { cells }\right)^{-1}\right]\end{array}$ \\
\hline None & - & $0 \cdot 8 \pm 0 \cdot 4$ \\
$\mathrm{NaCl}$ & 0.50 & $22 \cdot 2 \pm 0 \cdot 3$ \\
LiCl & $0 \cdot 50$ & $12 \cdot 7 \pm 0 \cdot 4$ \\
Mannitol & $1 \cdot 00$ & $1 \cdot 1 \pm 0 \cdot 2$ \\
Mannitol & 0.05 & $1 \cdot 5 \pm 0 \cdot 3$ \\
\hline
\end{tabular}




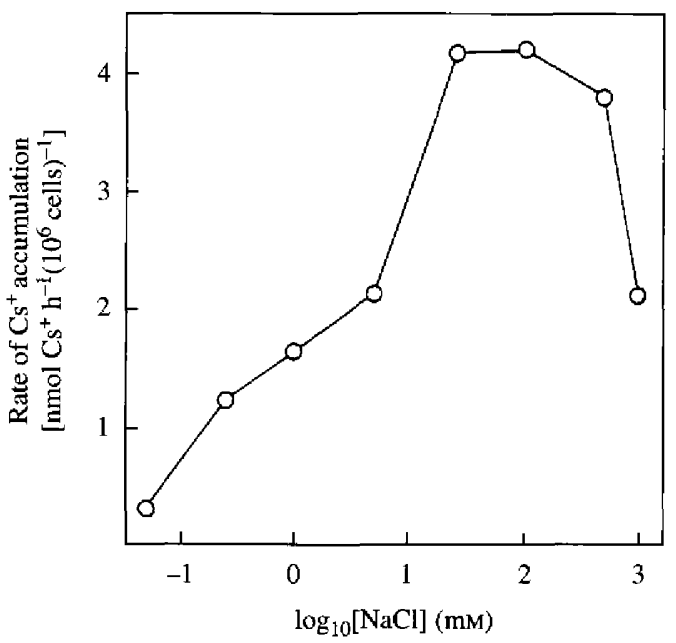

Fig. 1. Effect of $\mathrm{NaCl}$ on the rate of $\mathrm{Cs}^{+}$uptake by C. salina. Cells were suspended to $1 \times 10^{6} \mathrm{ml}^{-1}$ in $10 \mathrm{mM}$-TAPS buffer, adjusted to $\mathrm{pH} 8$ using tetramethylammonium hydroxide, supplemented with $50 \mu \mathrm{M}-$ $\mathrm{CsCl}$ and the appropriate concentration of $\mathrm{NaCl}$. Rates of $\mathrm{Cs}^{+}$uptake (O) were determined over the first $2 \mathrm{~h}$ incubation. Typical results from one of three experiments are shown.

$\left.0.3 \mathrm{nmol} \mathrm{Cs}{ }^{+} \mathrm{h}^{-1}\left(10^{6} \text { cells }\right)^{-1}\right]$, the lowest concentration examined, and increased to a maximum level of approximately $4 \mathrm{nmol} \mathrm{Cs}^{+} \mathrm{h}^{-1}\left(10^{6} \text { cells }\right)^{-1}$ between 25 and $500 \mathrm{~mm}-\mathrm{NaCl}$. The uptake rate was markedly reduced at $1 \mathrm{M}-\mathrm{NaCl}$ (Fig. 1).

The possibility of a $\mathrm{Cs}^{+}-\mathrm{Na}^{+}$symport in C. salina, which would account for the above observations, was investigated. However, although a clear stimulation of $\mathrm{Cs}^{+}$influx resulted from the addition of $\mathrm{Na}^{+}$to the external medium, any reciprocal stimulation of $\mathrm{Na}^{+}$ influx by $\mathrm{Cs}^{+}$was not discernible as ${ }^{22} \mathrm{Na}^{+}$uptake was complete within $30 \mathrm{~s}$ (data not shown). This was the fastest sampling time possible by the technique employed, and consequently rates of $\mathrm{Na}^{+}$uptake were not measured.

\section{Influence of $\mathrm{pH}$, divalent cations and cell density on $\mathrm{Cs}^{+}$ accumulation/removal by $C$. salina}

$\mathrm{Cs}^{+}$accumulation by $C$. salina was similar, after $2 \mathrm{~h}$ incubation, over a range of external $\mathrm{pH}$ values from pH 7 to 10 (data not shown). A slight increase in $\mathrm{Cs}^{+}$ accumulation was apparent at $\mathrm{pH} 8$, although this was only approximately $16 \%$ greater than at $\mathrm{pH} 7$.

$\mathrm{Mg}^{2+}$ and $\mathrm{Ca}^{2+}$ (supplied as chlorides) had no marked effect on $\mathrm{Cs}^{+}$accumulation by $C$. salina when supplied at 4 to 20 -fold higher concentrations than $\mathrm{CsCl}$ (data not shown).

Cell density had a marked effect on $\mathrm{Cs}^{+}$accumulation by $C$. salina (Fig. $2 a$ ). The rate of $\mathrm{Cs}^{+}$uptake, on a per cell basis, decreased with increasing cell density and, after $15 \mathrm{~h}$ incubation, the final levels of $\mathrm{Cs}^{+}$accumulated

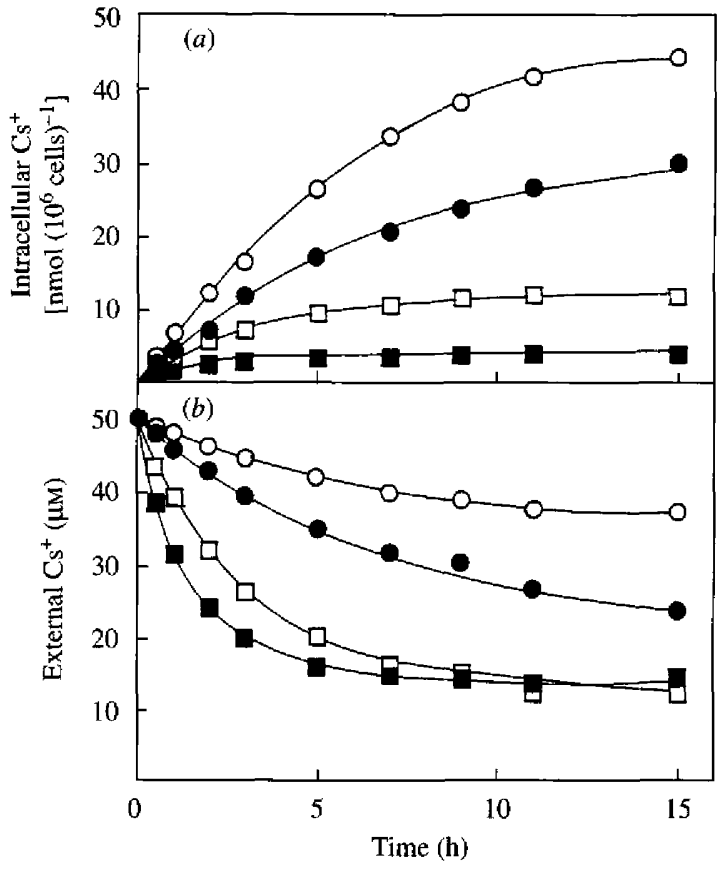

Fig. 2. Influence of cell density on $\mathrm{Cs}^{+}$accumulation by $C$. salina. Cells were suspended in $10 \mathrm{~mm}$-TAPS buffer $+0.5 \mathrm{M}-\mathrm{NaCl}, \mathrm{pH} 8$, supplemented with $50 \mu \mathrm{M}-\mathrm{CsCl}$. (a) $\mathrm{Cs}^{+}$accumulation at cell densities of $4 \times 10^{5}(\bigcirc), 1 \times 10^{6}(\bullet), 4 \times 10^{6}(\square)$ and $1 \times 10^{7}(\boldsymbol{C}) \mathrm{ml}^{-1}$. (b) Data from (a) transformed to represent $\mathrm{Cs}^{+}$remaining in solution. Mean values from three replicate determinations are shown. SE values were smaller than the dimensions of the symbols.

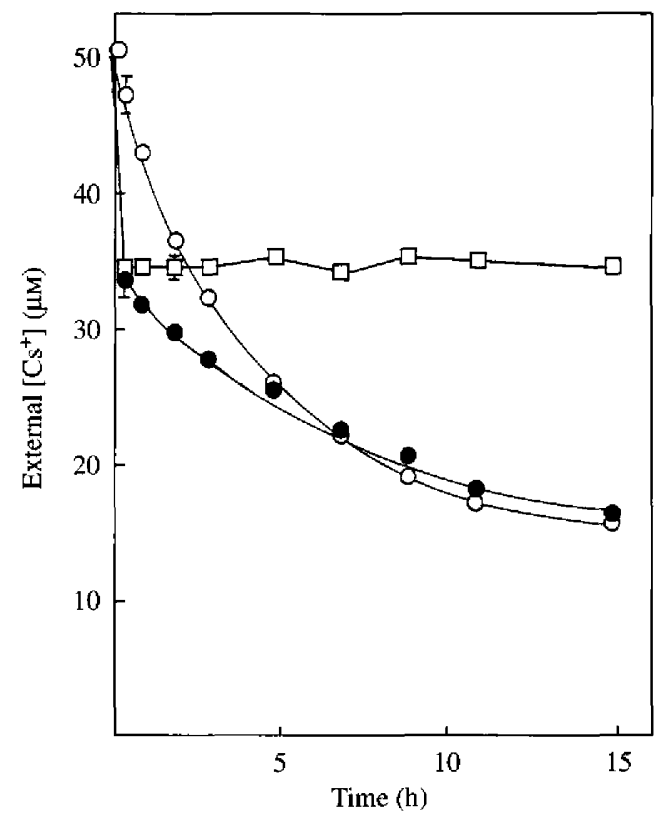

Fig. 3. Effect of immobilization on $\mathrm{Cs}^{+}$accumulation by $C$. salina. Cells (free and immobilized) were suspended to $1 \times 10^{6} \mathrm{ml}^{-1}$ in $10 \mathrm{~mm}$-TAPS buffer $+0.5 \mathrm{M}-\mathrm{NaCl}, \mathrm{pH} 8$, supplemented with $50 \mu \mathrm{M}-\mathrm{CsCl}$. The graph shows $\mathrm{Cs}^{+}$remaining in solution in the presence of free cells $(\mathrm{O})$, cells immobilized in beads ( $\bullet$ ) and cell-free beads $(\square)$. Mean values from three replicate determinations are shown \pm SE where these values exceed the dimensions of the symbols. 
Table 2. Uptake-efflux cycles for removal/recovery of $C s^{+}$by $C$. salina

Cells were suspended in $10 \mathrm{~mm}$-TAPS buffer $+0.5 \mathrm{M}-\mathrm{NaCl}, \mathrm{pH} 8$, supplemented with the appropriate amount of $\mathrm{CsCl}$. Cells were harvested after $15 \mathrm{~h}$, washed once in $10 \mathrm{~mm}$-TAPS buffer, adjusted to $\mathrm{pH} 8$ using tetramethylammonium hydroxide and supplemented with the specified amounts of $\mathrm{NaCl}, \mathrm{KCl}$ or mannitol, and then returned to the original $\mathrm{Cs}^{+}$-containing buffer. The washing procedure was repeated after 30 and $45 \mathrm{~h}$ of incubation. Mean values from three replicate determinations are shown \pm SE.

\begin{tabular}{|c|c|c|c|c|c|}
\hline \multirow{2}{*}{$\begin{array}{c}\mathrm{CsCl} \\
\text { concn } \\
(\mu \mathrm{M})\end{array}$} & \multirow[b]{2}{*}{ Addition to washing solution } & \multicolumn{3}{|c|}{ Percentage removal of $\mathrm{Cs}^{+}$after: } & \multirow{2}{*}{$\begin{array}{l}\text { Percentage } \\
\text { recovery of } \\
\text { accumulated } \\
\mathrm{Cs}^{+} \text {at } 15 \mathrm{~h}\end{array}$} \\
\hline & & $15 \mathrm{~h}$ & $30 \mathrm{~h}$ & $45 \mathrm{~h}$ & \\
\hline 50 & $0-50 \mathrm{~mm}-\mathrm{NaCl}$ & $71 \cdot 5 \pm 1 \cdot 2$ & $69 \cdot 7 \pm 0 \cdot 7$ & $69 \cdot 5 \pm 0 \cdot 6$ & $94 \cdot 8 \pm 1 \cdot 7$ \\
\hline 50 & $200 \mathrm{~mm}-\mathrm{NaCl}$ & $71 \cdot 5 \pm 1 \cdot 2$ & $76 \cdot 0 \pm 0 \cdot 0$ & $76 \cdot 0 \pm 0 \cdot 2$ & $67.9 \pm 0.2$ \\
\hline 50 & $500 \mathrm{mM}-\mathrm{NaCl}$ & $71 \cdot 5 \pm 1 \cdot 2$ & $75 \cdot 6 \pm 0 \cdot 0$ & $76 \cdot 3 \pm 0 \cdot 1$ & $4 \cdot 0 \pm 0 \cdot 0$ \\
\hline 50 & $500 \mathrm{~mm}-\mathrm{NaCl}+50 \mathrm{~mm}-\mathrm{KCl}$ & $71 \cdot 5 \pm 1 \cdot 2$ & $76.9 \pm 0.4$ & $77 \cdot 2 \pm 0.8$ & $82 \cdot 4 \pm 0 \cdot 0$ \\
\hline 50 & $500 \mathrm{~mm}-\mathrm{NaCl}+200 \mathrm{~mm}-\mathrm{KCl}$ & $71 \cdot 5 \pm 1 \cdot 2$ & $81 \cdot 8 \pm 0 \cdot 2$ & $85 \cdot 1 \pm 0 \cdot 1$ & $63 \cdot 9 \pm 0.2$ \\
\hline 50 & $500 \mathrm{~mm}-\mathrm{NaCl}+350 \mathrm{~mm}-\mathrm{KCl}$ & $71 \cdot 5 \pm 1 \cdot 2$ & $63 \cdot 6 \pm 0.6$ & $61 \cdot 4 \pm 0.5$ & $29 \cdot 3 \pm 0 \cdot 3$ \\
\hline 50 & $500 \mathrm{mM}-\mathrm{NaCl}+500 \mathrm{~mm}-\mathrm{KCl}$ & $71 \cdot 5 \pm 1 \cdot 2$ & $58.6 \pm 0.9$ & $52 \cdot 3 \pm 0.3$ & $12 \cdot 4 \pm 0 \cdot 1$ \\
\hline 50 & $250 \mathrm{~mm}-\mathrm{NaCl}+250 \mathrm{~mm}-\mathrm{KCl}$ & $71 \cdot 5 \pm 1 \cdot 2$ & $54 \cdot 8 \pm 1 \cdot 2$ & $51 \cdot 9 \pm 0 \cdot 0$ & $64.5 \pm 0.7$ \\
\hline 50 & $200 \mathrm{mM}-\mathrm{KCl}$ & $71.5 \pm 1.2$ & $45 \cdot 5 \pm 0.2$ & $32 \cdot 3 \pm 4.9$ & $11 \cdot 3 \pm 0.0$ \\
\hline 50 & $1 \mathrm{M}$-mannitol & $71 \cdot 5 \pm 1 \cdot 2$ & $52 \cdot 7 \pm 0.8$ & $48 \cdot 2 \pm 0 \cdot 1$ & $3 \cdot 4 \pm 0 \cdot 0$ \\
\hline 1 & $200 \mathrm{~mm}-\mathrm{NaCl}$ & $79 \cdot 3 \pm 0 \cdot 0$ & $85 \cdot 1 \pm 0 \cdot 2$ & $87 \cdot 8 \pm 0 \cdot 0$ & - \\
\hline 10 & $200 \mathrm{mM}-\mathrm{NaCl}$ & $79 \cdot 4 \pm 0 \cdot 1$ & $84 \cdot 9 \pm 7 \cdot 4$ & $87 \cdot 6 \pm 0 \cdot 0$ & - \\
\hline
\end{tabular}

were approximately $43 \cdot 6,29 \cdot 0,11 \cdot 4$ and $3 \cdot 2 \mathrm{nmol} \mathrm{Cs}^{+}$ $\left(10^{6} \text { cells }\right)^{-1}$ at cell densities of approximately $4 \times 10^{5}$, $1 \times 10^{6}, 4 \times 10^{6}$ and $1 \times 10^{7}$ cells ml ${ }^{-1}$, respectively (Fig. $2 a$ ). When the data were presented as $\mathrm{Cs}^{+}$remaining in solution during uptake at the varying cell densities, it was evident that the initial rate of $\mathrm{Cs}^{+}$removal increased with increasing cell density (Fig. $2 b$ ). At the highest cell density examined $\left(1 \times 10^{7}\right.$ cells ml $\left.{ }^{-1}\right)$, accumulation of $\mathrm{Cs}^{+}$was complete after approximately $7 \mathrm{~h}$ at which stage approximately $28 \%$ of $\mathrm{Cs}^{+}$remained in solution

\section{Removal of $\mathrm{Cs}^{+}$from solution by free and immobilized cells of C. salina}

Incubation of freely suspended cells of $C$. salina, and cells immobilized in calcium-alginate beads, in the presence of $50 \mu \mathrm{M}-\mathrm{CsCl}$ for $15 \mathrm{~h}$, resulted in an approximate $70 \%$ removal of external Cs ${ }^{+}$in both cases (Fig. 3). However, approximately one-half of that was attributable to binding of $\mathrm{Cs}^{+}$to the calcium-alginate matrix (determined by incubation of cell-free calcium-alginate beads alone). The results indicated that $C$. salina accumulated approximately $46 \%$ less $\mathrm{Cs}^{+}$when cells were present in an immobilized state than when in free suspension.

\section{Inhibition of growth of $C$. salina by $\mathrm{Cs}^{+}$}

Growth of $C$. salina in $\mathrm{MN}$ medium was similar in the absence or presence of $50 \mu \mathrm{M}-\mathrm{CsCl}$, with a cell doubling time during the exponential growth phase of $2.4 \mathrm{~d}$ and a final cell yield after $35 \mathrm{~d}$ incubation of approximately $9.2 \times 10^{7}$ cells ml ${ }^{-1}$ (data not shown). However, growth of C. salina was inhibited at $1 \mathrm{~mm}-\mathrm{CsCl}$; the cell doubling time was increased by approximately $41.7 \%$ and the final cell yield reduced by approximately $68.5 \%$, in comparison to cells incubated in the absence of $\mathrm{CsCl}$.

Uptake efflux cycles for removal/recovery of $\mathrm{Cs}^{+}$by $C$. salina

The efficacy of repeated incubations of $C$. salina in removal of $\mathrm{Cs}^{+}$from solution was investigated (Table 2). Approximately $71.5 \% \mathrm{Cs}^{+}$was removed after $15 \mathrm{~h}$ incubation of C. salina in buffer in the presence of $50 \mu \mathrm{M}$ $\mathrm{CsCl}$ and approximately $95 \%$ of accumulated $\mathrm{Cs}^{+}$was released when cells were subsequently washed in buffers of lower osmotic strength, containing $0-50 \mathrm{~mm}-\mathrm{NaCl}$. At higher $\mathrm{NaCl}$ concentrations, a lower proportion of cellular $\mathrm{Cs}^{+}$was released and negligible $\mathrm{Cs}^{+}$loss resulted at $500 \mathrm{mM}-\mathrm{NaCl}$. Re-incubation of the cells for a second $15 \mathrm{~h}$ period, in the original $\mathrm{Cs}^{+}$-containing buffer, resulted in little or no further $\mathrm{Cs}^{+}$accumulation. In all of the above cases, further accumulation of $\mathrm{Cs}^{+}$did not occur during a third incubation period (Table 2).

The inclusion of increasing amounts of $\mathrm{KCl}$ in washing solutions containing $500 \mathrm{~mm}-\mathrm{NaCl}$ resulted in decreased levels of $\mathrm{Cs}^{+}$release. However, the greatest percentage removal of $\mathrm{Cs}^{+}$, approximately $85.1 \%$ after three successive $15 \mathrm{~h}$ incubations, occurred when cells were washed in buffer containing $500 \mathrm{~mm}-\mathrm{NaCl}$ and $200 \mathrm{~mm}$ $\mathrm{KCl}$. Washing cells in other combinations of $\mathrm{NaCl}, \mathrm{KCl}$ 
and mannitol resulted in lower final levels of $\mathrm{Cs}^{+}$removal. The percentage removal of $\mathrm{Cs}^{+}$was increased when cells were incubated in the presence of 1 and $10 \mu \mathrm{M}-\mathrm{CsCl}$ (Table 2). After incubation periods totalling $45 \mathrm{~h}$, $>87 \%$ of the initial amount of $\mathrm{Cs}^{+}$was accumulated at these lower $\mathrm{CsCl}$ concentrations. Further enhancement of $\mathrm{Cs}^{+}$removal was achieved by using either fresh buffer or fresh cells for the second incubation period (data not shown).

\section{Discussion}

Although it is generally considered that inorganic ions, e.g. $\mathrm{K}^{+}$, play a role in the osmoregulation of halotolerant microalgae (Gilmour, 1990), there is some controversy as to their relative importance in osmo-adaptation compared to organic solute accumulation/synthesis (Ginzberg \& Ginzberg, 1986). In the present work, $\mathrm{Cs}^{+}$influx in $C$. salina was markedly stimulated in the presence of $\mathrm{NaCl}$ indicating that, in contrast to E. coli (Macaskie, 1991), the $\mathrm{K}^{+}$transport system that mediates $\mathrm{Cs}^{+}$uptake by $C$. salina is under osmotic control. Rates of $\mathrm{Cs}^{+}$ uptake at low $\mathrm{NaCl}$ concentrations $(\leqslant 50 \mu \mathrm{M}-\mathrm{NaCl})$ were comparable to those observed previously for the freshwater microalga Chlorella emersonii in the absence of $\mathrm{NaCl} ; \mathrm{NaCl}$ inhibited $\mathrm{Cs}^{+}$uptake by $C$. emersonii (Avery et al., 1992b). The stimulatory effect of $\mathrm{NaCl}$ and $\mathrm{LiCl}$ on $\mathrm{Cs}^{+}$uptake by C. salina was not mirrored by mannitol when supplied at an equivalent osmotic strength to the salts. It was concluded that the present observations with $\mathrm{Cs}^{+}$were due to a specific effect of $\mathrm{NaCl}$ and $\mathrm{LiCl}$, rather than a general osmotic effect. In certain diatoms the operation of $\mathrm{K}^{+} / \mathrm{Na}^{+}$symports has been described (Brown \& Hellebust, 1978), although any reciprocal stimulation of $\mathrm{Na}^{+}$uptake by $\mathrm{Cs}^{+}$in C. salina was not discernible in this study due to a very rapid accumulation of ${ }^{22} \mathrm{Na}^{+}$. It should be stressed that other mechanisms besides a symport may also explain the current observations. Ehrenfeld \& Cousin $(1982,1984)$ have postulated that $\mathrm{K}^{+} / \mathrm{Na}^{+}$exchange occurs in the halotolerant Dunaliella tertiolecta to counteract the large passive influx of $\mathrm{Na}^{+}$that follows hypertonic shock. However, Pick et al. (1986) proposed that increased $\mathrm{K}^{+}$ uptake and $\mathrm{Na}^{+}$extrusion, following osmotic shock in $D$. salina, may be unrelated secondary effects resulting from an activation of the plasma membrane $\mathrm{H}^{+}$-ATPase.

The low level of inhibition of $\mathrm{Cs}^{+}$uptake by other monovalent cations in C. salina (Avery et al., 1993), and by the divalent cations $\mathrm{Mg}^{2+}$ and $\mathrm{Ca}^{2+}$ reported here, suggests that problems frequently caused by the presence of competing ions on metal removal processes (Gadd, 1990) may not be so important in the present system. Furthermore, in contrast to the marked $\mathrm{pH}$-dependence of $\mathrm{Cs}^{+}$accumulation by the cyanobacterium Synecho- cystis PCC 6803 (Avery et al., 1991), high $\mathrm{Cs}^{+}$uptake levels were maintained over a range of external $\mathrm{pH}$ values in $C$. salina.

Despite the increased removal of $\mathrm{Cs}^{+}$from solution at higher cell densities of $C$. salina, decreased amounts of $\mathrm{Cs}^{+}$were accumulated per cell. This is similar to results obtained for cobalt uptake by C. salina (Garnham et al., 1991) and may be attributed to a decrease in the availability of exogenous solute (Meikle et al., 1990) in addition to shading of incident light at high cell densities. Decreased $\mathrm{Cs}^{+}$accumulation was also observed in immobilized cells of $C$. salina. Immobilization has negligible influence on the photosynthesis of $C$. salina but results in a $30 \%$ decrease in the rate of respiration (Garnham et al., 1992). $\mathrm{Rb}^{+}$and $\mathrm{Cs}^{+}$influx, in Chlorella pyrenoidosa and $C$. emersonii, respectively, are independently supported by cyclic photophosphorylation and oxidative phosphorylation (Springer-Lederer \& Rosenfeld, 1968; Avery et al., 1992 b). It is likely that a reduction in respiration would also result in a decline in $\mathrm{Cs}^{+}$uptake in immobilized C. salina.

Hypo-osmotic shock of $\mathrm{Cs}^{+}$-loaded cells resulted in loss of the accumulated ion as was the case for $\mathrm{K}^{+}$in the halotolerant microalga Chlorococcum submarinum (Blackwell \& Gilmour, 1991). Such treatment is known to have negligible effect on the growth or structural integrity of C. salina (Wong et al., 1979; Garnham et al., 1991). At very low salinities, the proportion of cellular $\mathrm{Cs}^{+}$that was released approached $100 \%$. However, washing cells in buffer containing $500 \mathrm{~mm}-\mathrm{NaCl}$ and $200 \mathrm{~mm}-\mathrm{KCl}$, between successive incubation periods, resulted in the highest final level of $\mathrm{Cs}^{+}$removed, approximately $85 \cdot 1 \%$. Unfortunately, the removal efficiency of $\mathrm{Cs}^{+}$by $C$. salina was reduced during successive incubation periods. Further experiments (data not shown) indicated that this reduced uptake was partly due to increased competition from $\mathrm{K}^{+}$released by cells in exchange for $\mathrm{Cs}^{+}$. In addition, washing procedures that allowed cells to retain the greatest capacity for further $\mathrm{Cs}^{+}$uptake failed to remove all cellular $\mathrm{Cs}^{+}$. As a consequence, subsequent accumulation of $\mathrm{Cs}^{+}$, to a final level equal to that obtained prior to washing, only required reduced uptake.

The maximal level of $\mathrm{Cs}^{+}$uptake reported here $[85.1 \%$ removal from $\left.50 \mu \mathrm{M}-\mathrm{Cs}^{+}, \sim 42.6 \mathrm{nmol}\left(10^{6} \text { cells }\right)^{-1}\right]$ corresponds to approximately $66 \mathrm{mg} \mathrm{Cs}^{+}\left(\mathrm{g} \mathrm{dry} \mathrm{wt}^{-1}\right.$. This is lower than the value of $150 \mathrm{mg}$ metal ( $\mathrm{g}$ dry wt $)^{-1}$ suggested by Brierley et al. (1986) as being a threshold below which biological metal-removal becomes commercially non-viable, although it must be stated that environmental considerations did not take priority in this assessment. Although no improvement in $\mathrm{Cs}^{+}$uptake efficiency resulted from cell immobilization, advantages of this process over many other living cell systems 
include its $\mathrm{pH}$-independence, the low toxicity of $\mathrm{Cs}^{+}$ towards $C$. salina and the non-destructive treatments that may be employed for complete recovery of accumulated $\mathrm{Cs}^{+}$. Furthermore, despite the probable influence of external $\mathrm{K}^{+}$on $\mathrm{Cs}^{+}$accumulation following successive incubation periods, competition by $\mathrm{K}^{+}$is low in $C$. salina (Avery et al., 1993) compared to certain other microorganisms (Avery et al., 1992a), and the influence of other naturally abundant ions like $\mathrm{Ca}^{2+}$ and $\mathrm{Mg}^{2+}$ was negligible. The application of recently gained knowledge to the present system, e.g. the nutritional-regime dependence of $\mathrm{Cs}^{+}$uptake in phototrophic microorganisms (Avery et al., 1992b) and possibilities arising from the selective isolation of $\mathrm{Cs}^{+}$-accumulating microorganisms (Tomioka et al., 1992) may prove useful in further enhancing $\mathrm{Cs}^{+}$-removal efficiencies by halotolerant micro-organisms in an applied context.

S.V.A. gratefully acknowledges the receipt of a NERC postgraduate research studentship for the work described.

\section{References}

AVERY, S. V. \& ToBin, J. M. (1992). Mechanisms of strontium uptake by laboratory and brewing strains of Saccharomyces cerevisiae. Applied and Environmental Microbiology 58, 3883-3889.

Avery, S. V., Codd, G. A. \& GADD, G. M. (1991). Caesium accumulation and interactions with other monovalent cations in the cyanobacterium Synechocystis PCC 6803. Journal of General Microbiology 137, 405-413.

AverY, S. V., CoDD, G. A. \& GADD, G. M. (1992a). Interactions of cyanobacteria and microalgae with caesium. In Impact of Heavy Metals on the Environment, pp. 133-182. Edited by J.-P. Vernet. Amsterdam: Elsevier.

Avery, S. V., Codd, G. A. \& GADD, G. M. (1992b). Replacement of cellular potassium by caesium in Chlorella emersonii: differential sensitivity of photoautotrophic and chemoheterotrophic growth. Journal of General Microbiology 138, 69-76.

Avery, S. V., CODD, G. A. \& GADD, G. M. (1993). Transport kinetics, cation inhibition and intracellular location of accumulated caesium in the green microalga Chlorella salina. Journal of General Microbiology 139, 827-834.

Blackwell, J. R. \& Gilmour, D. J. (1991). Physiological response of the unicellular green alga Chlorococcum submarinum to rapid changes in salinity. Archives of Microbiology 157, 86 91 .

Brierley, J. A., Goyak, G. M. \& Brierley, C. L. (1986). Considerations for commercial use of natural products for metal recovery. In
Immobilisation of Ions by Biosorption, pp. 105-117. Edited by H. Eccles \& S. Hunt. Chichester: Ellis Horwood.

Brown, L. M. \& Hellebust, J. A. (1978). Ionic dependence of deplasmolysis in the euryhaline diatom Cyclotella cryptica. Canadian Journal of Microbiology 56, 408-412.

Ehrenteld, J. \& Cousin, J.-L. (1982). Ionic regulation of the unicellular green alga Dunaliella tertiolecta. Journal of Membrane Biology 70, 47-57.

Ehrenfeld, J. \& Cousin, J.-L. (1984). Ionic regulation of the unicellular green alga Dunaliella tertiolecta: response to hypertonic shock. Journal of Membrane Biology 77, 45-55.

GADD, G. M. (1990). Fungi and yeasts for metal accumulation. In Microbial Mineral Recovery, pp. 249-275. Edited by H. L. Ehrlich, C. L. Brierley \& J. A. Brierley. New York: McGraw-Hill.

GADD, G. M. (1992). Microbial control of heavy metal pollution. In Microbial Control of Pollution, pp. 59-88. Edited by J. C. Fry, G. M. Gadd, R. A. Herbert, C. W. Jones \& I. Watson-Craik. Cambridge: Cambridge University Press.

Garnham, G. W., Codd, G. A. \& Gadd, G. M. (1991). Effect of salinity and $\mathrm{pH}$ on cobalt biosorption by the estuarine microalga Chlorella salina. Biology of Metals 4, 151-157.

Garnham, G. W., CoDD, G. A. \& GADD, G. M. (1992). Uptake of cobalt, zinc and manganese by the estuarine green microalga Chlorella salina immobilized in alginate microbeads. Environmental Science and Technology 26, 1764-1770.

GILMoUr, D. (1990). Halotolerant and halophilic microorganisms. In Microbiology of Extreme Environments, pp. 147-177. Edited by C. Edwards. Milton Keynes: Open University Press.

GinZBuRG, M. \& GINZBURG, B.-Z. (1986). The osmotic components of halotolerant algae: unanswered questions. Trends in Biochemical Sciences 11, 359-360.

MACASKIE, L. E. (1991). The application of biotechnology to the treatment of wastes produced from the nuclear fuel cycle: biodegradation and bioaccumulation as a means of treating radionuclidecontaining streams. Critical Reviews in Biotechnology 11, 41-112.

MEIKLE, A. J., GADD, G. M. \& ReED, R. H. (1990). Manipulation of yeast for transport studies: critical assessment of cultural and experimental procedures. Enzyme and Microbial Technology 12, 865-872.

Pick, U., Ben-Amotz, A., Karni, L., Seebergts, C. J. \& Avron, M. (1986). Partial characterization of $\mathrm{K}^{+}$and $\mathrm{Ca}^{2+}$ uptake systems in the halotolerant alga Dunaliella salina. Plant Physiology 81, 875-881.

Plato, P. \& Denovan, J. T. (1974). The influence of potassium on the removal of ${ }^{137} \mathrm{Cs}$ by live Chlorella from low level radioactive wastes. Radiation Botany 14, 37-41.

SPRINGER-LEDERER, H. \& RoSENFELD, D. L. (1968). Energy sources for the absorption of rubidium by Chlorella. Physiologia Plantarum 21 , 435-444.

Tomioka, N., UchiYama, H. \& Yagi, O. (1992). Isolation and characterization of cesium-accumulating bacteria. Applied and Environmental Microbiology 58, 1019-1023.

Walderhaug, M. O., Dosch, D. C. \& Epstein, W. (1987). Potassium transport in bacteria. In Ion Transport in Prokaryotes, pp. 85-130. Edited by B. P. Rosen \& S. Silver. New York: Academic Press.

Wong, K. H., Chan, K. Y. \& NG, S. L. (1979). Cadmium uptake by the unicellular green alga Chlorella salina CU-1 from culture media with high salinity. Chemosphere 11/12, 887-891. 